\title{
Competence of Special Committee Members of Regional People's Representative Assembly
}

\author{
La Ode Sahili ${ }^{1}$, Usman Rianse², Gunawan ${ }^{2}$, Muhammad Nur Yamin ${ }^{3}$ \\ ${ }^{1}$ Halu Oleo University, Doctoral Program of Management Science, Kendari, Southeast Sulawesi, Indonesia \\ ${ }^{2}$ Halu Oleo University, Agriculture Faculty, Kendari, Southeast Sulawesi, Indonesia \\ ${ }^{3}$ Halu Oleo University, Social Science Faculty, Kendari, Southeast Sulawesi, Indonesia \\ ${ }^{4}$ Halu Oleo University, Social Science Faculty, Kendari, Southeast Sulawesi, Indonesia
}

\begin{abstract}
The purpose of study was to analyze and identify the competencies that can predict the performance of the Special Committee Members of Regional People's Representative Assembly, District of Konawe. The approach of this study was qualitative focuses on four areas of competence, which consist of competence, professional competence, political competence and ethical competence. Data collected included primary and secondary data. The informants determined by purposive technique of data collection are interviews, observation, and study documents. Spradley follow the model of data analysis that includes descriptive observation, analysis domain, focused observation, taxonomic analysis, observation elected componential analysis and thematic analysis. The results showed that legislators actually have competence, professionalism, and ethics not as expected or better yet, with the exception of political competence that is already good, to be able to perform well. This study presents empirical evidence to the theoretical model of a public manager's competence Virtanen (1982). The model can predict the value and instrumental competencies that consist of competence, professional competence, political competence and ethical competence affect the performance of public managers. In general, the findings of this study support this argument. Performance of Special Committee of People's Representative Assembly, district of Konawe that has not been good is consistent with state legislators whose competence is also not good. Implications of these findings was that the study of the science of public management competencies in the future needs to include the development of a theoretical framework that optimizes the performance of public sector organizations are political structures in the region include environmental conditions such as human security and moral incentives.
\end{abstract}

Keywords: Competence, Special Committee Member

\section{Introduction}

Local government consists of executive and legislative (the Regional Representatives Council) aims to provide maximum service to the community. The Executive is the regional administration based on policies set with the Regional Representatives Council (DPRD), while Representative is a partner in the executive or legislative function make local regulations; which together make up the executive budget revenue and expenditure budget (APBD); and oversight of the wheels of government under the applicable laws and budgeting that is open and accountable.

Legislative Council in carried out its duties and powers, supplemented by a few fittings. One fittings Representative is a special committee that formed when any regulations will discussed as needed and agreed to finalize a regulation or a decision that will be discussed legislators.

The public expects that the special committee of Representative is performing valuable, not only because the tasks of the Special Committee of Regional People's Representative Assembly is covering the common good or the common good (Rueschemeyer \& Evans, 2002), but also because it works with public money (Atkinson, 2005). Performance defined as a valuable outcome of the behavior of individuals in achieving the objectives of the organization (Bernardin et al., 1995).
The main key special committee of Regional People's Representative Assembly in order to be able to perform is valuable in carrying out the functions, duties and authority is competence. Mc. Clelland (1973) put forward the proposition of competence is a critical differentiator of performance in the various clusters of life. Boyatzis (2007) said that competence could predict performance in the role of the professional, management and leadership in many sectors of society. Competence refers to the capability to perform effectively (Mulder, 2011). Competence is a combination of explicit knowledge, attitudes, and skills that give someone the potential to display the effective discharge (Draganidis and Mentzas, 2006). Model that can accurately described the phenomenon of performance of Special Committee of Parliament is a competency framework of public managers Virtanen (2000), includes four areas of competence required of successful public managers, namely: (1) the competence areas of duty; (2) professional competence in the field of substantive policy and administrative fields; and (4) political competence; and (5) ethical competence.

Initial studies of the outcomes of the special committee of Regional People's Representative Assembly Konawe not provide strong enough evidence to be called to perform as part of the special committee can complete its mandated tasks though controversial, and others cannot complete the task until it enters a period of The next Regional People's Representative Assembly membership. It also includes a function of weakness in the field of legislation that Regional 


\section{International Journal of Science and Research (IJSR) \\ ISSN (Online): 2319-7064 \\ Index Copernicus Value (2013): 6.14 | Impact Factor (2014): 5.611}

People's Representative Assembly has not done the right of initiative in proposing draft local regulations (Ranperda). The result of local regulations during the period 2009-2014 was the program entirely from local legislation initiated by the local government. Everything regarded as conduct that is not of value in the context of good governance and modern. Based on the empirical background of the study aims to analyze the competencies are actually owned by legislators Konawe.

Competence is a key concept in human resource management. Horton, Hondeghem and Farnham (2002) suggests the concept of competence as well as developing competency management and first applied in private businesses and then transferred to the public sector around the 1980s and 1990s in line with the emergence of the New Public Management (NPM). Boyatzis (2008) defines competence: "A competency is defined as a capability or ability". Capability refers to a set of behaviors that based on a strong desire or intent. The definition of competence Spencer and Spencer (1993) "... an underlying characteristic of an individual, that is causally related to criterion-referenced effective and / or superior performance in a job or situation.". Hsieh, Lin and Lee (2012) suggested that the definition that most referenced by researchers and more detailed about competence by Parry:

"A competency is a cluster of related knowledge, skills, and attitudes that Affects a major part of one's job (a role or responsibility), that correlates with performance on job, that can be measure against well-accepted standards, and that can be improved via training and development. ". Competence is thus a fundamental characteristic of people who related with performance-related positions with an outlook that is used where most authors focus on individual characteristics or behavioral while the other focused on the requirements of the job.

Bozkurt (2011: 28) states that the competency model is a set of competencies that together determine the effective performance in specific work settings, pointing at a group of competence needed in a certain position. Competency models Spencer and Spencer (1993) includes six individual characteristics, namely: (1) skills, (2) knowledge, (3) the concept of self,(4) the nature (trait), (5) motif, and (6) the attitude / value. Spencer and Spencer stated that the competence to resemble an iceberg. Competency model of Horton, Hondeghem and Farnham (2002) covers the core competencies and competency subsidiary. Core competencies are essential for a person to do a particular position on a competitive basis. Organizations, according to Horton and colleagues can have different types of core competencies.

There is widespread recognition that contextual competence which positions and different organizations require different competencies, although there are competencies that may be the same for all types of positions or organizations (Boyatzis, 1982). This is true for politicians in local government, in particular the Special Committee of Regional People's Representative Assembly. Related to this competency framework of public managers Virtanen (2000) includes five areas of competence required by a successful public managers, namely: (1) the competence of duty; (2) professional competence in substantive policy areas; (3) professional competence in the field of administration; (4) political competence; and (5) ethical competence. Competency framework public managers of Virtanen includes capabilities instrumental exalted in public administration theory traditionally the competence areas of duties and professional competence in the field of administration, and the values developed by the new public management that is of professional competence in the field of policy substantive, political competence, and ethical competence.

Virtanen framework used in this study for consideration of compatibility with the research setting that public sector organizations. Five areas of competence within the framework of Virtanen simplified into four areas, namely: the competence of duty; (2) professional competencies, (3) political competence; and (4) ethical competence. Professional competence in the field of substantive policy and professionals in the field of administration united into one area of competence, namely professional competence. Pagon, Banutai, and Bizjak (2008) do simplification.

Competence often called specific competencies duty office, or technical competence. This competence refers to the type of knowledge, theories, methods, and skills that are relevant or necessary to carry out the completion of tasks in a "group office" (OECD, 2013; Hsieh, Lin and Lee, 2012). To be able to perform effectively in presenting these important tasks, Hildebrandt said five of the most important factors of personal ability, namely credibility, responsibility, interpersonal skills, assertiveness (Resolute), and energy (Petersen, 2006). Professional competence refers to the capability to display a certain professional tasks in an acceptable quality. The definition of the profession according to Davis (1988) is a position group that organized according to the characteristics of the skills of its members to the public good. In this regard, Mayhew (2015) identified several professional competences, namely: focus on the client, integrative thinking, problem solving, and self-evaluation.

Political competence refers to the elements of the skills necessary to carry out the political tasks successfully (Alcántara, 2008). Political competence is defined as well as the personal skills needed by legislators to perform the duties of political (Roson, in Alcantara, 2008).Elemen-element of political competence, according to Alcantara (2008: 4) include education and political career. Pagon, Banutai, and Bizjak (2008: 4) argue that political competence can be seen from the steadiness of ideologies and interests as well as the possession of power. Ethics refers to those standards that have a clear basis in respect of right and wrong, and determine what people should do (Amundsen and Andrade, 2009). Ethical competence refers to the capability to apply power ethically. Rules of conduct in the exercise of power can be reduced to three general rules, namely: (1) act responsible; (2) avoid conflicts of interest; and (3) do not hurt / harm (Whitton, 2007). Another suggestion, Moore (1976), suggests that public sector obligations arise from three areas the following: (1) respect for the processes that legitimize the actions of public officials; (2) serves a broad

\section{Volume 5 Issue 3, March 2016}




\section{International Journal of Science and Research (IJSR) \\ ISSN (Online): 2319-7064 \\ Index Copernicus Value (2013): 6.14 | Impact Factor (2014): 5.611}

public interest; and (3) treating colleagues and clients with respect, honest, and fair.

\section{Materials and Methods}

This study in the context of the work of the Special Committee Konawe Regency Southeast Sulawesi Province used a qualitative approach with descriptive analysis method. Research activity is characterized by the activities of collecting, describing and interpreting data about the situation experienced, certain relationships, activities, views, attitudes shown or trends are apparent in the ongoing process, opposition tapered, and the cooperation is executed members of the special committee of Regional People's Representative Assembly Konawe

Table 1: Focus research of competence special committee members of Regional People's Representative Assembly, District of Konawe

\begin{tabular}{|c|c|c|}
\hline Concept & Dimensions & Attributes \\
\hline \multirow{13}{*}{$\begin{array}{l}\text { Competence } \\
\text { of Regional } \\
\text { People's } \\
\text { Representativ } \\
\text { e Assembly } \\
\text { Members }\end{array}$} & \multirow{4}{*}{$\begin{array}{c}\text { Task } \\
\text { Competence }\end{array}$} & a) Credibility. \\
\hline & & b) inter - personal skills \\
\hline & & \begin{tabular}{|l|} 
c) The firmness. \\
\end{tabular} \\
\hline & & d ) Energy \\
\hline & \multirow{4}{*}{$\begin{array}{l}\text { Professional } \\
\text { Competence }\end{array}$} & a) Focus on the client's interests. \\
\hline & & b) The ability to problem -solving. \\
\hline & & $\begin{array}{l}\text { c) Ability to specify the policy } \\
\text { objectives. }\end{array}$ \\
\hline & & d) The ability to allocate resources \\
\hline & \multirow{3}{*}{$\begin{array}{c}\text { Political } \\
\text { Competence }\end{array}$} & a) Political education \\
\hline & & b) Political Career \\
\hline & & c) Ownership attributes of power \\
\hline & \multirow{2}{*}{$\begin{array}{c}\text { Ethics } \\
\text { Competence }\end{array}$} & a) Ability to act responsible \\
\hline & & $\begin{array}{l}\text { b)The ability to avoid conflicts of } \\
\text { interest }\end{array}$ \\
\hline
\end{tabular}

Key concepts that are the focus of this research in the conceptualization as follows:

1) Competence is a capability that owned by members of Regional People's Representative Assembly Konawe to perform effectively in implementing the tasks of the Special Committee with respect to legislation, budget and supervision.

2) Competence is the task of the theoretical and methodical knowledge of relevant owned by legislators Konawe to carry out general duties of public office.

3) Professional competence is the capability to display specific professional duties on the committee which is owned by legislators Konawe.

4) Political competence are the elements necessary skills to carry out political tasks owned by members of Regional People's Representative Assembly Konawe.

5) Ethical competence is the capability to implement the ethical power possessed by legislators Konawe.

\section{Informants Selection Techniques}

The subjects of this study are legislators Konawe totaling 30 people, and as the member of Special Committee - Regional People's Representative Assembly Konawe. Decision informant is purposive, elected Informant: Chairman of the Committee special meeting, Secretary of the Committee special meeting, the Chairman of Regional People's Representative Assembly Konawe, and 1 staff secretariat of Regional People's Representative Assembly Konawe, Elements Government (Regent or Regional Secretary), Elements of Political Parties, Expert Political and Election Commission chairman Konawe.

The techniques of data collection in this study consist of; a)participant observation, conducted by researchers participating in the interaction and routines research subject, by observing about what they were doing, absorb, explore their behavior in interacting, and follow the process of implementation services, and locate important information pertaining to this study;

b)In-depth interviews and the corresponding interview guidelines focused research guided;

c) Study documents, collection of secondary data relating to the performance of members of the Special Committee of Regional People's Representative Assembly Konawe as a foundation for understanding the phenomena related to the object of this study.

Data analysis techniques in the model consists of Spradley, descriptive observation, analysis domain, focused observation, taxonomic analysis, observation elected, componential analysis and thematic analysis. It shows that the implementation of the research carried out between alternating between data collection to data analysis ultimately, study the overall problem missed. Competence in research divided into several dimensions, where each dimension represented by the description of the behavior of indicators that show the degree of competence of different (good or less good). Differences in each level made in such a way to recognized to facilitate the assessors accurately determine the level of competence that owned by someone. The process of checking the validity of data done with reference to: (1) credibility by extending the observation period; continuous observation; (2) Trianggulasi; discuss with various parties is competent; analyzing the negative case; by references; do check.

\section{Result and Discussion}

The description of competencies organized into four areas of competence, namely: competence, professional competence, political competence, and competence of conduct, reflecting the instrumental capabilities in traditional public administration theory and values developed by public management. Instrumental covers task areas of competence and professional competence, while the values of competence include political and ethical competence. The results of the empirical findings of this study indicate that in all four areas of competence have not wholly owned by legislators Konawe. In other words, has not reached the level that expected to be able to perform effectively.

Not maximum competence indicated tasks: (1) The credibility attributes possessed by most members of the legislature; (2) attributes interpersonal skills are minimal owned by the majority of members of Regional People's Representative Assembly; (3) lack of firmness attributes 


\section{International Journal of Science and Research (IJSR) \\ ISSN (Online): 2319-7064 \\ Index Copernicus Value (2013): 6.14 | Impact Factor (2014): 5.611}

possessed by most members of the legislature; (4) energy attributes possessed by most members of Regional People's Representative Assembly. Not maximum professional competence are indicated: (1) legislators are generally less focused on the interests of the client; (2) legislators generally have less problem-solving abilities; and (3) DPRD members generally lack the ability to allocate resources. Already good political competence are indicated: (1) the political education of members of Regional People's Representative Assembly on the path to formal school is adequate but political enlightenment in an informal setting is still weak; (2) the political career of a majority of legislators monotonous and static; (3) members of Regional People's Representative Assembly have the attribute of power potential. Furthermore, not maximum ethical competences are indicates: (1) members of Regional People's Representative Assembly are not entirely responsible act in the completion of the task; and (2) legislators were less consistent avoid conflicts of interest in the community area.

Table 2: Summary of Findings Member Competence of Regional People's Representative Assembly District of Konawe

\begin{tabular}{|c|c|c|}
\hline $\begin{array}{c}\text { Competence } \\
\text { Area } \\
\end{array}$ & Indicators & Attributes \\
\hline \multirow{4}{*}{$\begin{array}{c}\text { Task } \\
\text { Competence }\end{array}$} & a) Credibility. & $\begin{array}{l}\text { 1)Most of Regional People's Representative Assembly members have speech quality and consistent } \\
\text { behavior. } \\
\text { 2)A small number of Regional People's Representative Assembly members do not have the quality of } \\
\text { speech and behavior are Consistent, namely : talkative little behaved, and a little bit of talk but } \\
\text { also act in the execution of the task }\end{array}$ \\
\hline & $\begin{array}{l}\text { b. Inter - personal } \\
\text { skills }\end{array}$ & $\begin{array}{l}\text { 1)Most Regional People's Representative Assembly members have only one or two attributes } \\
\text { interpersonal skills. } \\
\text { 2)Few Regional People's Representative Assembly members who have finally provides abilities to } \\
\text { speak, communicate through writing, and a positive attitude when interacting }\end{array}$ \\
\hline & c ) The firmness & $\begin{array}{l}\text { 1) In general, members tend to gain time to make compromises and make a decision ahead of the } \\
\text { deadline. } \\
\text { 2) In general, Regional People's Representative Assembly members are easily influenced by the } \\
\text { direction of structural or interests }\end{array}$ \\
\hline & d ) Energy & $\begin{array}{l}\text { 1) Most of the members of Regional People's Representative Assembly have health and good } \\
\text { physical endurance. } \\
\text { 2) Most of Regional People's Representative Assembly members have a good spiritual milieu }\end{array}$ \\
\hline \multirow{3}{*}{$\begin{array}{l}\text { Professional } \\
\text { Competence }\end{array}$} & $\begin{array}{l}\text { a) Focus on the } \\
\text { client's interests. }\end{array}$ & $\begin{array}{l}\text { 1) Members of Regional People's Representative Assembly have been trying but do not understand } \\
\text { the essential needs of the wider community. } \\
\text { 2) Members of Regional People's Representative Assembly are less able to meet the needs of } \\
\text { priority that have lasting impact for the wider community }\end{array}$ \\
\hline & $\begin{array}{l}\text { b) The ability to } \\
\text { problem -solving }\end{array}$ & $\begin{array}{l}\text { 1) Members of Regional People's Representative Assembly are generally less able to recognize and } \\
\text { define the problem of public priorities. } \\
\text { 2) Members of Regional People's Representative Assembly are generally less able to propose a } \\
\text { viable solution to the problem of public priorities. }\end{array}$ \\
\hline & $\begin{array}{l}\text { c) The ability to } \\
\text { allocate resources }\end{array}$ & $\begin{array}{l}\text { 1)Members of Regional People's Representative Assembly are less able to push the budget } \\
\text { allocation in accordance with the mission of local government and public policy direction } \\
\text { agreed upon with the local government. } \\
\text { 2)Members of Regional People's Representative Assembly tend to encourage technical and }\end{array}$ \\
\hline \multirow{3}{*}{$\begin{array}{c}\text { Political } \\
\text { Competence }\end{array}$} & $\begin{array}{l}\text { a) Political } \\
\text { education }\end{array}$ & $\begin{array}{l}\text { 1)Members of Regional People's Representative Assembly most of the formal school backgrounds } \\
\text { who teaches political science or political socialization. } \\
\text { 2) Members of Regional People's Representative Assembly are mostly involved in an informal } \\
\text { setting while focusing even more on imagery than to enlighten or political learning }\end{array}$ \\
\hline & $\begin{array}{l}\text { b ) Political } \\
\text { Career }\end{array}$ & $\begin{array}{l}\text { 1) Most Regional People's Representative Assembly members have a lawyer- care positions of } \\
\text { political parties, but few are moving linearly upward. } \\
\text { 2) Some members of Regional People's Representative Assembly have the experience of sitting in } \\
\text { parliament more than one period but at a level / the same area. }\end{array}$ \\
\hline & $\begin{array}{l}\text { c ) Ownership } \\
\text { attributes of } \\
\text { power }\end{array}$ & $\begin{array}{l}\text { 1) Members of Regional People's Representative Assembly all have a common education level } \\
\text { above the average of the community. } \\
\text { 2) Members of Regional People's Representative Assembly generally have financial wealth above } \\
\text { the community average in the region, and most are classified as middle economic class }\end{array}$ \\
\hline \multirow[b]{2}{*}{$\begin{array}{c}\text { Ethics } \\
\text { Competence }\end{array}$} & $\begin{array}{l}\text { a) Ability to act } \\
\text { responsible }\end{array}$ & $\begin{array}{l}\text { 1) Members of Regional People's Representative Assembly are all involved in the implementation } \\
\text { of the tasks in accordance with their authority. } \\
\text { 2) Members of Parliament did not adopt most of the processes that are expected for task completion }\end{array}$ \\
\hline & $\begin{array}{l}\text { b) The ability to } \\
\text { avoid conflicts of } \\
\text { interest }\end{array}$ & $\begin{array}{l}\text { 1) Members of Regional People's Representative Assembly are less active early detection of causes } \\
\text { of potential conflict of interest. } \\
\text { 2) Resolution of conflicts of interest has not been shown consistently in all areas of Regional } \\
\text { People's Representative Assembly member's duties. } \\
\text { 3) Regional People's Representative Assembly members responsive resolve the conflict in a type of } \\
\text { intra group conflict. }\end{array}$ \\
\hline
\end{tabular}




\section{International Journal of Science and Research (IJSR) \\ ISSN (Online): 2319-7064}

Index Copernicus Value (2013): 6.14 | Impact Factor (2014): 5.611

The findings of this study indicated that competence of Konawe legislators on the task area, professional and ethical everything has not reached the expected level, with the exception of political competence is already good. According to Virtanen (2000) and Pagon, Banutai, and Bizjak (2008), competence, professional competence, political competence and ethical competence are all factors the explanation behind every successful public managers. Members of Regional People's Representative Assembly including public managers, and to be able to carry out public duties with success, legislators need competence in all four areas. The lack of good competence by legislators Konawe risk that the performance of its duties has the potential to fail or not be successful. The importance of having the attributes of the job competence, according to Hildebrandt in Petersen (2006), OECD (2013) and Hsieh, Lin and Lee (2012) is to be able to perform effectively in displaying the daily tasks by the private and public sector managers.

Less possesses the attributes of competency task by legislators Konawe interpreted that Regional People's Representative Assembly lacked the structural instrument for performing effective in displaying the tasks of everyday in the field of legislation, budget and supervision. Lack of professional competence held by legislators Konawe and the area of competence of the weakest of the four competency areas covered in this research model. Christensen and Laegreid (2008) describe the essence of professional competence, namely: people-oriented "what do I need to do differently", what do I need to be able to do anything differently. He does not have the attributes of professional competence by legislators Konawe can be interpreted that they are not a true professional and not modern public officials who understand what is needed to be able to do anything differently.

Konawe Assembly Members already have good political competence. The majority of legislators have formal political education, which is studying political science and / or the political socialization through the formal curriculum. Some members of Regional People's Representative Assembly are involved in a number of potential informal setting for political enlightenment, legislators utilize informal settings is still limited to perform imaging yet to achieve enlightenment political capacity. Most legislators have a position as a board of political parties, and have experience as a Member of Regional People's Representative Assembly more than one period.

Importance of ownership attributes of political competence by Pagon, Banutai, and Bizjak (2008) is for the creation and authorization to the goals of the public, as well as the creation and provision of resources to support these goals. This capacity is important for Regional People's Representative Assembly, as a function of Regional People's Representative Assembly is to establish and agree on common policies together with the Regional Head. Ethical competence shared by members of Regional People's Representative Assembly Konawe is low. Members of Regional People's Representative Assembly have not acted sufficiently responsible in the completion of the task, and less consistent in avoiding conflicts of interest are widespread in society. To control it remained on the right track (the legislators) require standards of right and wrong, and it is the essence of ethics (Amundsen and Andrade, 2009). The weakness of competence conduct suggests that Regional People's Representative Assembly can hardly expected to consistently work to the benefit of the public interest in general.

Theoretically, competence is a critical differentiator of performance in the various clusters of life (McClelland, 1973). Special Committee of Regional People's Representative Assembly in particular, and Regional People's Representative Assembly in general, is a type of profession, and the people who run it are professionals. The findings of this study, that the competence is owned by members of Regional People's Representative Assembly Konawe in the areas of duty, professional, political and ethical, is low, interpreted that profession DPRD having instruments. The findings of this study indicate that the competencies possessed by members of Regional People's Representative Assembly in general are inadequate. This illustrates that the legislative branch of government in the sector do not have the instruments Konawe maximum performance drivers. Furthermore, the general duty of Regional People's Representative Assembly is the legislative, budget and oversight, it can be said this function in local governance Konawe hardly be expected to be able to good perform. Competence not only in explaining the performance on average, competence can produce superior performance (Boyatzis, 1982) , Superior performance is required in order to optimize the achievement of organizational goals both in the private sector organizations and the public sector.

\section{Conclusions}

In general, this study presents the results of empirical evidence to the theoretical model of the public manager's competence Virtanen. The model can predict the value and instrumental competency that consists of competence, professional competence, political competence and ethical competence affect the performance of public managers. In general, the findings of this study support this argument. Performance Special Committee of Konawe Regional People's Representative Assembly that has not been good showed that consistent with state legislators whose competence is also not good.

Efforts to improve the competence of members of the legislature requires the efforts of political parties through regeneration party members who become candidates for legislative and administrative arrangements will be requisite education (college) and a lifetime membership in political parties for support, and length of stay in the area it represents.

\section{References}

[1] Alcántara, M. The Political Competence of Representatives in Latin America: An Analysis of Eleven National Cases. Prepared for delivery at the 2008 Annual Meeting of the American Political Science Association, August 28-31, 2008

\section{Volume 5 Issue 3, March 2016}




\section{International Journal of Science and Research (IJSR) \\ ISSN (Online): 2319-7064}

Index Copernicus Value (2013): 6.14 | Impact Factor (2014): 5.611

[2] Amundsen, Inge, and Vicente Pinto de Andrade (Editors), Public Sector Ethics: Compendium for Teaching. January 2009. Luanda and Bergen. Tersedia online pada www.cmi.no/publications/.../3290introduction-to.. 2009.

[3] Bernardin, H., and Russel, E. A., Human resource Management: An Experiential Approach. Singapore: McGraw Hill Book Co. 1995.

[4] Bozkurt, AY., "Management By Competencies", Istanbul [March, 2011]. Diakses dari http://www.risusinternational.com>uploads. 2011.

[5] Boyatzis, R. E. The Competent Manager: A Model for Effective Performance. New York: John Wiley \& Sons. 1982.

[6] Christensen, T., and Lægreid, P. Transcending New Public Management: The Transformation of Public Sector Reforms. Hampshire, England: Ashgate Publishing Limited. 2008.

[7] Davis, Michael. Professionalism Means Putting Your Profession First. Georgetown Journal of Legal Ethics, Vol 2, 341-357. 1988.

[8] Horton, S., Hondeghem, A., and Farnham, D. (editors), Competency Management in the Public Sector: European Variations on a Theme. EGPA Monograph. Netherlands: IOS Press. 2002.

[9] Hsieh, Su-Chin, Lin, Jui-Shin, and Lee, Hung-Chun, "Analysis on Literature Review of Competency". International Review of Business and Economics, Vol. 2, pp. 25-50. 2012.

[10] Mayhew, Ruth. Listing Professional Competencies. Demand Media. Tersedia online pada http://work.chron.com/listing-professionalcompetencies - 20980.html. 2015.

[11] McClelland, David C. Memacu Masyarakat Berpartisipasi, Jakarta: Intermedia. 1987

[12] McClelland, David C. The Achieving Society. Toronto: D. Van Nostrand Company, Inc. 1973.

[13] Mulder, M., "The Concept of Competence: Blessing or Curse? In I. Torniainen, S. Mahlamäku-Kultanen, P. Nokelainen \& P. Ilsley (Eds). Innovations for Competence Management. Lahti: Lahti University of Applied Sciences, pp. 11-24. 2011

[14] Pagon, M., Emanuel Banutai, and Uroš Bizjak, Leadership Competencies For Successful Change Management: A Preliminary Study Report. Slovenian Presidencu of the EU. Available online at https://www.oeffentlicherdienst.gv.at/.../leadership. 2008.

[15] Petersen, P. Top management Competencies: An Investigation Into The Top 100 Private And Public Companies In The Faroes. Dissertation Submitted in fulfilment of the award of MSc. in Management (Public edition). Robert Gordon University, Aberdeen, Aberdeen Business School. Tersedia online pada www.industry.fo/.../Download.aspx?. 2006.

[16] Spencer, L.M, and Spencer, S.M,. Competence At Work. John Willey \& Sons, New York. 1993.

[17] Virtanen, Turo, "Changing Competences of Public Managers: Tensions in Commitment". The International Journal of Public Sector Management. Vol 13 (4). Pages 333 - 341. 2000.
[18] Whitton, H., "Developing the Ethical Competence of Public Officials: A Capacity-building Approach". Viešoji Politika Ir Administravimas, 2007, Nr. 21, pp. 49-60. 2007. 